\title{
Morpho-anatomical features of the flower Tulipa biebersteiniana Schult. et Schult. in the South of the Central Russian Upland
}

\author{
Tatyana Glubsheva ${ }^{1 *}$, Vladimir Cherniavskih ${ }^{1,2,3}$, Elena Dumacheva ${ }^{1,2,3}, \quad$ Oxana \\ Vorobyova $^{1}$, and Svetlana Grigorenko ${ }^{I}$ \\ ${ }^{1}$ Belgorod State National Research University, Belgorod, 308015, RussianFederation \\ ${ }^{2}$ Federal State Budgetary Scientific Institution «Federal Scientific Center for Forage Production and \\ Agroecology named after V.R. Williams», 141055, Lobnya, Moscow reg.,Russia \\ ${ }^{3}$ State Scientific Institution "All-Russian Research Institute of Phytopathology", Russian Agricultural \\ Academy", 143050, Bolshie Vyazemy, Odintsovo distr., Moscow reg., Russia
}

\begin{abstract}
The processes of formation of many species are observed in the south of the Central Russian Upland. For these conditions, the morphoanatomical features of the tepals of Tulipa biebersteiniana Schult. Et. Schult. fil as the adaptive potential of seed propagation were studied for the first time. The tepals are arranged in two circles and differ in morphological and anatomical features. Differences in the structure of the main cells of the epidermis on the abaxial and adaxial sides were revealed. On the abaxial side, the main epidermal cells are rectangular, sometimes fusiform or rarely diamond-shaped, arranged in rows. They are covered with a weakly longitudinally wrinkled cuticle. The side walls of the abaxial surface are straight or slightly curved. On the adaxial surface, the side walls are zigzag, passing to the lateral edge in strongly sinuous. The localization, estimated functions and sizes of the hairs on the leaves of the tulip were determined. Single celled trichomes are located in two places. Keywords: Tulipa biebersteiniana, tulipa, seed propagation.
\end{abstract}

\section{Introduction}

Landscape and climatic conditions of ecotopes of ravine-beam complexes with Cretaceous outcrops in the south of the Central Russian Upland form the conditions for the preservation and development of unique flora [1]. The study of the number and distribution of individuals by age groups indicates the stability of adaptive micro evolutionary changes occurring in populations [2-6], which allows us to consider the south of the Central Russian Upland to be a secondary anthropogenic microgen center of species formation [7-9].

The northern edge of the Tulipa biebersteiniana range is this area. The East EuropeanAsian species is a stolon-forming ephimeroid-geophyte. It is found in shrubs, steppe areas, and forest edges. The demographic strategy of the Tulipa biebersteiniana is associated with the implementation of seed and vegetative reproduction. Depending on the habitat (mineral nutrition, soil density, light), anthropogenic impact, age of the plant, one or another strategy prevails. Seeds are formed or a different number of plagiotropic propagation stolons are

* Corresponding author: glubsheva@bsu.edu.ru 
formed [10-12]. At the same time, T. biebersteiniana plants are characterized by high potential and low real seed productivity [6]. Seed propagation is a response to unstable external conditions. Along with an increase in seed productivity at the organizational level, the habit of plants decreases, and stolon formation increases. At the population level, there is an increase in the density and number of individuals, there is a shift in the age spectrum to the left, that is, there is a predominance of pre-generative and generative plants in the population. As ephemeroid T. biebersteiniana implements a stress-protective ontogenetic strategy and features of patientsthe and explaintory. Patientestis manifested in avoidance of competition with the later vegetative species in the community in a way of going into a state of rest. Explerency manifests itself through intensive reproduction in the absence of competition to occupy new territories. The traits of explerency increase with increasing of stress.

The ontogenesis and rhythms of seasonal development, the morphogenesis of its shoots, and some aspects of seed reproduction of T. biebersteiniana, were studied [6, 13-14]. At the same time, the peculiarities of the flower's adaptation to seed reproduction are not fully revealed. As a research goal, the authors identified an attempt to assess the presence of morpho-anatomical features of the flower T. biebersteiniana in connection with the generative strategy, despite the absence or low real seed productivity.

\section{Materials and methods}

The samples of live plants of T. biebersteiniana of seven local populations growing on the territory of the Vejdelevskij and Krasnogvardejskij districts of the Belgorod region were the material for the study. The samples were taken in April during the mass flowering period. Ten flowers were taken from each population for the study. Anatomy was studied according to generally accepted methods [15-16]. The epidermis was examined on temporary preparations prepared from the top and base of the cup-shaped and corollashaped leaves of a simple perianth of a tulip flower. The repetition is tenfold. The main cells of the epidermis were evaluated by length, width, number of cells per $1 \mathrm{~mm}^{2}$, cell shape, and type of side walls. Studying stomata, the length, width of the closing cells, the length of the stomatal fissure, and the number of stomata in $1 \mathrm{~mm}^{2}$ along the central veins were measured. The hairs were evaluated by length, width, and shape. The obtained measurements allowed us to calculate the values for determining the type of the main cells of the epidermis, the stomatal coefficient, and the type of stomatal apparatus. The dissection was performed using a passing light micro-imager $\mu$ Vizo-103 at various magnifications.

\section{Results and discussion}

T. biebersteiniana has an actinomorphic, bisexual, star-shaped flower with clearly expressed rhythms of closing and opening, depending on temperature, degree of illumination, stage of development. The parts of the flower are arranged in circles (Fig. 1, 2).

The leaves of the simple perianth have noticeable differences. The cup-shaped leaves form an outer circle, they are more elongated, have a length of 25-35 mm, a width of 7-10 $\mathrm{mm}$. The corolla-shaped leaves make up the inner circle, they are shorter and much wider. Their sizes are $20-35 \mathrm{~mm}$ and 10-20 mm, respectively. The leaflets have a bright yellow color, a rolled boat and a pointed tip, the cup-shaped leaflets show a gray-green stripe in the middleonly on the abaxial side The leaves of the perianth grow rapidly due to the alternate 
division of the cells of the inner and outer sides. The increase in length is $2 \mathrm{~mm}$ or more, and the width is up to $0.5 \mathrm{~mm}$ per day.

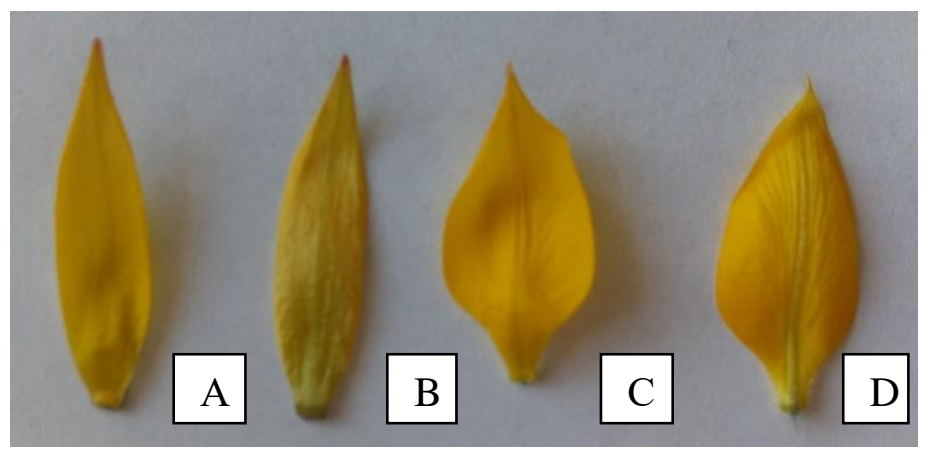

Fig. 1. Leaves of the simple perianth of T. biebersteiniana:A - adaxially side checkvideo leaf, B abaxially side checkvideo leaf, $\mathrm{C}$-adaxially side Corolla leaf, D -abaxially side Corolla leaf.

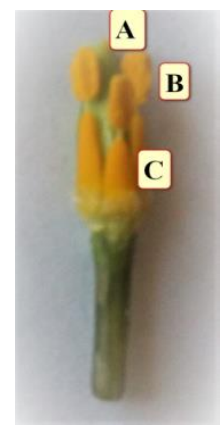

Fig. 2. Generative parts of the flower: A-pistil, B-long stamen of the inner circle, C-short stamen of the outer circle.

Further inside the flower, the stamens are arranged in two circles: the short stamens of the outer circle and the long stamens of the inner circle. The staminate filaments and anthers are equally yellow (Fig. 2).

There is a pistil, consisting of a three-lobed stigma covered with sticky liquid with hairs, and a column smoothly passing into the ovary in the center. The color of the pistil is light green. The length of the pestle is $1.2-1.3 \mathrm{~cm}$, the width is $2-5 \mathrm{~mm}$. The size of the pistil in the populations does not vary much $(2-5 \%)$.

The anatomical structure of the tepals ensures the performance of its characteristic functions. They serve to attract pollinating insects, create conditions for the growth and development of generative parts of the flower, and promote fertilization and seed formation (Lotova, 2001). Anatomically, the leaves consist of four types of tissues: the epidermis, the main, mechanical and conductive tissues. The main cells of the epidermis as the primary integumentary tissue are associated with the protection of organs from temperature changes, pathogens, light, and evaporation [15]. They are located on the surface of the leaf and have a typical structure for the epidermis. Species differences are associated with the shape of cells and the sinuosity of the side walls, the deposition of silica in the cell membranes, the presence of cuticles, the type and size of hairs, the type and location of stomata, and other features. The study of the anatomical structure of the leaflets allowed us to establish the contribution of the epidermis of the tepals to the implementation of the seed propagation strategy of the Bieberstein tulip.

The results of the study revealed that the epidermis of the leaves differs depending on the circle, side (abaxial, adaxial) and even on the surface itself. The cells of the top of the 
epidermis of the adaxial side are rectangular, sometimes of fusiform or rarely of diamondshaped (Fig. 3), arranged in rows. They are covered with a weakly longitudinally wrinkled cuticle. The size of the cells does not vary much: the length is $0.18 \mathrm{~mm}$, the width is 0.03 $\mathrm{mm}$, there are about 227 cells in $1 \mathrm{~mm}^{2}$ (Table 1). The size of the base cells does not change significantly. The length of the cells is $0.14 \mathrm{~mm}$, and the width is $0.04 \mathrm{~mm}$, there are about 210 cells in $1 \mathrm{~mm}^{2}$. In this case, the ratio of length to width varies from 6 to 3.5. The cells of the apex of the epidermis of the abaxial side are also rectangular, sometimes of fusiform or rarely of diamond-shaped. The length of the cells is $0.27 \mathrm{~mm}$, the width is 0.03 $\mathrm{mm}$, that is, the epidermal cells on the outer surface of the apex are longer than on the inner surface. The size of the cells to the base is reduced: the length is up to $0.14 \mathrm{~mm}$, and the width is up to $0.02 \mathrm{~mm}$. The ratio of the linear dimensions of the epidermal cells of the base of the outer side are at the level of their ratio at the top of the inner side. The side walls of the abaxial surface are straight or slightly curved. On the adaxial surface, the side walls are zigzag, passing to the lateral edge in strongly sinuous.
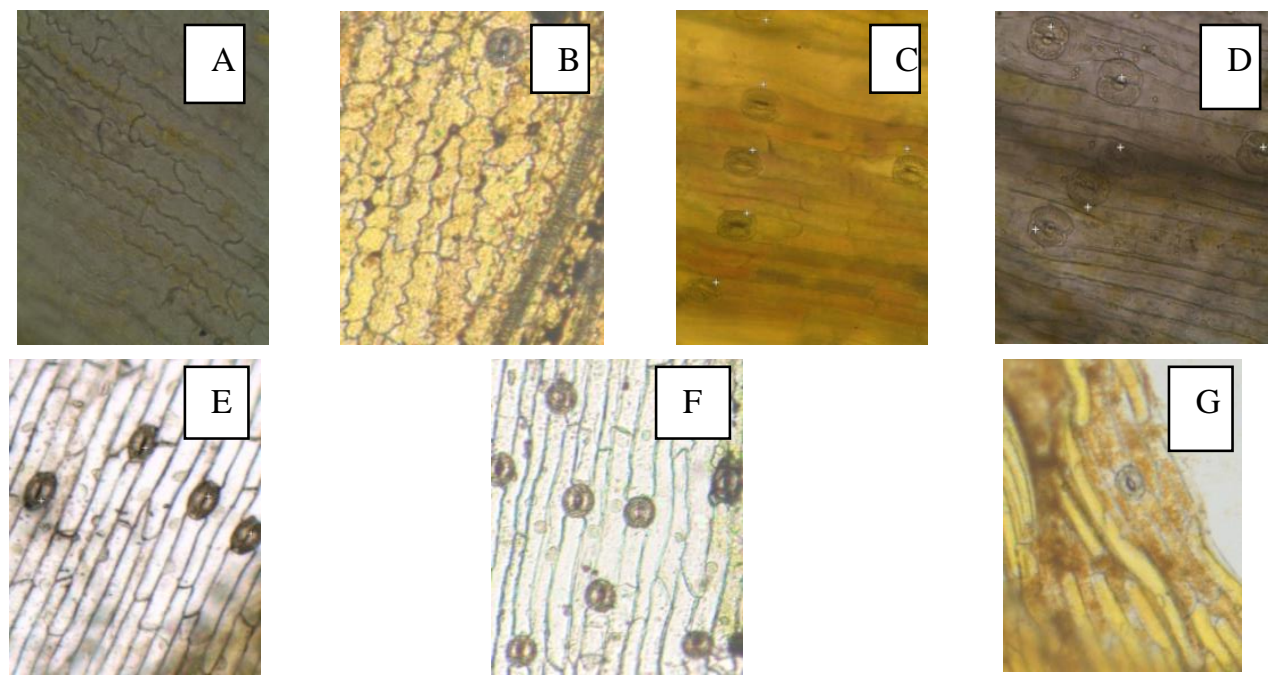

Fig. 3. Epidermis (magnifying 250): A - base checkvideo leaf, adaxial side, B - In the top of checkvideo leaf, adaxial side, $\mathrm{C}$ - tip checkvideo leaf, abaxial side, D - checkvideo base of leaf, abaxial side, E - tip of the Corolla of leaf, abaxial side, F - Corolla base of leaf, abaxial side, G Corolla base of leaf, adaxial side.

The thickening of the cell walls is uniform in the form of solid lines of the same thickness. Sometimes there are cells with a rosary-shaped thickening, where the cell walls are represented as dotted lines due to the pores formed in the cell walls. The outer wall of the cell is covered with a layer of cuticle. Cutin precursors are synthesized by the protoplast of epidermal cells, pass through the outer wall in the form of a liquid intermediateproduct. It oxidizes, polymerizes and hardens in the air, and it leads to the formation of cuticles. Sometimes the cutin does not come out of the cell wall. And then it, along with cellulose, pectin substances and wax, create protection for the surface of plant organs [16]. The leaves of the tulip are dominated by a longitudinal wrinkled cuticle.

The cells of the epidermis of the apex of the corolla-shaped leaflet of the adaxial side are rectangular, rarely of fusiform, andare arranged in rows (Fig. 3). They are covered with a weakly longitudinally wrinkled cuticle. The size of the cells does not vary much: the length is $0.16 \mathrm{~mm}$, the width is $0.04 \mathrm{~mm}$, there are about 161 cells in $1 \mathrm{~mm}^{2}$ (Table 2).

The size of the cells at the base increases. The length of the cells is $0.22 \mathrm{~mm}$ and the width is $0.04 \mathrm{~mm}$. The ratio of length to width is about 4-6. The cells of the apex of the 
epidermis of the abaxial side are also rectangular, sometimes of fusiform or rarely of diamond-shaped.

The length of the cells is $0.23 \mathrm{~mm}$, the width is $0.02 \mathrm{~mm}$, that is, the epidermal cells on the outer surface of the apex are 1.4 times longer than on the inner surface. The size of the cells towards the base decreases: the length is up to $0.16 \mathrm{~mm}$, with a width of $0.03 \mathrm{~mm}$. The ratio of the linear size of the epidermal cells on the outer side is of the greatest importance and is about 11. The epidermis of the corolla-shaped leaflets with a thick uniform cuticular layer attracts attention. The cells of the epidermis of the adaxial side of the corolla leaf contain a large number of chromoplasts (Fig. $5 \mathrm{G}$ ), so the flower opened, it becomes more vivid.

There are hairs on the surface of the leaves of the tulip. They are localized in two places. This is the tip of the adaxial surface of the cup-shaped and corolla-shaped leaflets (Fig. 4).

Table 1. Features of the cells of the epidermis of the cup-shaped leafT. biebersteiniana

\begin{tabular}{|c|c|c|c|c|}
\hline \multirow{2}{*}{\begin{tabular}{c} 
Characteristic \\
\cline { 2 - 5 }
\end{tabular}} & \multicolumn{2}{|c|}{ abaxial side } & \multicolumn{2}{c|}{ adaxial side } \\
\hline $\begin{array}{c}\text { The length of the epidermis cells, } \\
\mathrm{mm}\end{array}$ & $0.27 \pm 0.019$ & $0.14 \pm 0.007$ & $0.18 \pm 0.013$ & $0.14 \pm 0.008$ \\
\hline $\begin{array}{c}\text { The width of the epidermis cells, } \\
\mathrm{mm}\end{array}$ & $0.03 \pm 0.001$ & $0.02 \pm 0.001$ & $0.03 \pm 0.001$ & $0.04 \pm 0.003$ \\
\hline The ratio of length to width,\% & 9 & 5.8 & 6 & 3.5 \\
\hline $\begin{array}{c}\text { Number of epidermal cells, } \\
\text { pcs/mm }{ }^{2}\end{array}$ & $142.4 \pm 7.19$ & $295.5 \pm 9.34$ & $227.2 \pm 8.23$ & $210.4 \pm 12.47$ \\
\hline $\begin{array}{c}\text { Number of stomata, pc/ mm }{ }^{2} \\
\text { Stomatal coefficient, \% }\end{array}$ & $45.2 \pm 2.16$ & $33.4 \pm 0.85$ & singular & $0.45 \pm 0.045$ \\
\hline $\begin{array}{c}\text { The length of the stomata, mm } \\
\text { The width of the stomata, mm }\end{array}$ & $0.054 \pm 0.0011$ & $0.07 \pm 0.001$ & $0.14 \pm 0.055$ & $0.18 \pm 0.004$ \\
\hline $\begin{array}{c}\text { Length of the stomatal fissure, mm } \\
\text { The ratio of the length to the width } \\
\text { of the stomata, } \%\end{array}$ & $0.022 \pm 0.52$ & $0.033 \pm 0.0007$ & $0.013 \pm 0.009$ & $0.08 \pm 0.001$ \\
\hline $\begin{array}{c}\text { The ratio of the length of the } \\
\text { stomata to the length of the } \\
\text { stomatal fissure, } \%\end{array}$ & 1.2 & 1.8 & 0.9 & 1.2 \\
\hline The presence of hairs & no & no & much & no \\
\hline $\begin{array}{c}\text { The length of the hairs, mm } \\
\text { The width of the hairs, mm }\end{array}$ & - & - & $0.05 \pm 0.002$ & - \\
\hline \begin{tabular}{c} 
The \\
\hline
\end{tabular} & - & - & $0.03 \pm 0.0003$ & - \\
\hline
\end{tabular}

The hairs are unicellular, short 0.05-0.014 mm long and $0.03 \mathrm{~mm}$ wide, with a welldefined cell wall, nucleus, chromoplasts, and a cavity inside. Therefore, such glandular hairs may possibly take part in the release of various substances. Such hairs are also called papillae. They are low, wide outgrowths of epidermal cells. The abundance of papillae creates a velvety surface of the leaf. In addition, pollen accumulates between them (Fig. 4 $\mathrm{C}$ ), which is of great strategic importance. The perianth of the tulip is characterized by dynamic movements that lead to periodic opening and closing of the flowers, which protects the stamens and pistil from adverse weather conditions, and also creates a supply of pollen at the top of the flower. Even if the flower does not open at the time of pistil maturation due to unfavorable conditions, there is pollen inside for cross-pollination, and it is located next to the wet stigma. 
Table 2. Features of the cells of the epidermis of the corolla-shaped leaf of T. biebersteiniana

\begin{tabular}{|c|c|c|c|c|}
\hline \multirow[t]{2}{*}{ Characteristic } & \multicolumn{2}{|c|}{ abaxial side } & \multicolumn{2}{|c|}{ adaxial side } \\
\hline & the tip & footing & the tip & footing \\
\hline $\begin{array}{l}\text { The length of the epidermis } \\
\text { cells, mm }\end{array}$ & $0.23 \pm 0.001$ & $0.16 \pm 0.007$ & $0.16 \pm 0.006$ & $0.22 \pm 0.020$ \\
\hline $\begin{array}{l}\text { The width of the epidermis } \\
\text { cells, mm }\end{array}$ & $0.02 \pm 0.001$ & $0.03 \pm 0.001$ & $0.04 \pm 0.003$ & $0.04 \pm 0.003$ \\
\hline The ratio of length to width, $\%$ & 11.5 & 5.3 & 4 & 5.5 \\
\hline $\begin{array}{l}\text { Number of epidermal cells, } \\
\text { pcs } / \mathrm{mm}^{2}\end{array}$ & $188.2 \pm 8.43$ & $201.3 \pm 12.48$ & $161.1 \pm 10.3$ & $138.0 \pm 10.30$ \\
\hline Number of stomata,шт/ $\mathrm{mm}^{2}$ & $41.8 \pm 0.01$ & $32.1 \pm 2.60$ & no & $17.0 \pm 1.22$ \\
\hline Stomatal coefficient, $\%$ & 11.4 & 13.8 & - & 11.0 \\
\hline The length of the stomata, $\mathrm{mm}$ & $0.05 \pm 0.001$ & $0.06 \pm 0.001$ & - & $0.07 \pm 0.002$ \\
\hline The width of the stomata, $\mathrm{mm}$ & $0.05 \pm 0.0001$ & $0.03 \pm 0.001$ & - & $0.03 \pm 0.001$ \\
\hline $\begin{array}{l}\text { Length of the stomatal fissure, } \\
\mathrm{mm}\end{array}$ & $0.02 \pm 0.001$ & $0.02 \pm 0.001$ & - & $0.03 \pm 0.002$ \\
\hline $\begin{array}{l}\text { The ratio of the length to the } \\
\text { width of the stomata, } \%\end{array}$ & 1 & 2 & - & 2.3 \\
\hline $\begin{array}{l}\text { The ratio of the length of the } \\
\text { stomata to the length of the } \\
\text { stomatal fissure, } \%\end{array}$ & 3.3 & 3 & - & 2.3 \\
\hline The presence of hairs & no & no & much & much \\
\hline The length of the hairs, $\mathrm{mm}$ & - & - & $0.14 \pm 0.009$ & $0.4 \pm 0.17$ \\
\hline The width of the hairs, $\mathrm{mm}$ & - & - & $0.03 \pm 0.001$ & $0.04 \pm 0.001$ \\
\hline
\end{tabular}
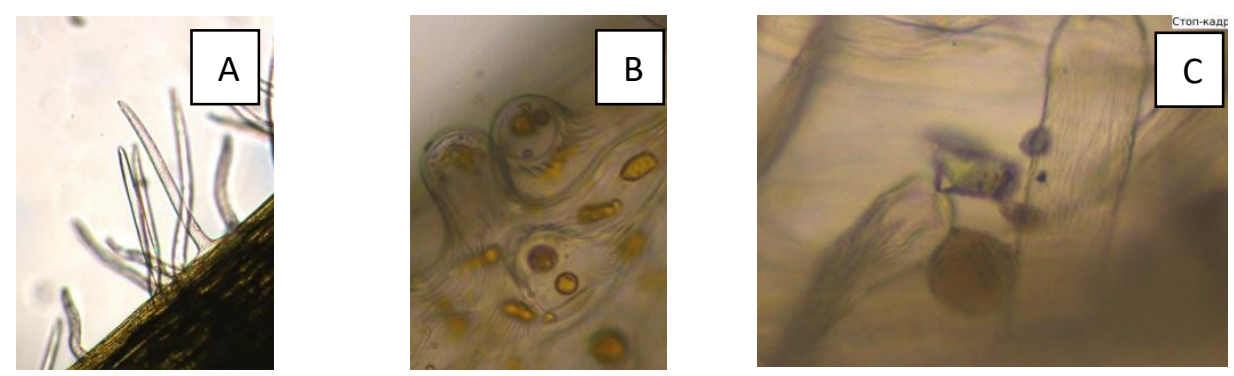

Fig. 4. Hairs: A-bases of the corolla-shaped leaflet, adaxial side (magnifying 250), B-apex of the corolla, adaxial side (magnifying 250), C - the tip of the cup-shaped leaf, adaxial side (magnifying 1000)/

In addition, single-celled hairs occur on the lateral surface of the base of the corollashaped leaflets with an offset to the adaxial side. They differ in their filamentous shape. Their length is $0.4 \mathrm{~mm}$, width $0.04 \mathrm{~mm}$, that is, three times longer than the apical ones. It is clear that these are independent cells, along with the epidermal ones, slightly protruding 
above the surface (Fig. 4 A). Most likely, such covering trichomes can take part in protecting the flower from excessive loss of moisture from the semi-closed flower and temperature. The tulip is an entomophilic plant, which has pronounced primary attractant features: an abundance of pollen, nectar, as well as numerous hairs rich in nutrients located at the base of the stamens and the pistil. An insect that has flown to a flower disperses pollen not only on the stigma for direct pollination, but also can leave it in reserve between the hairs on the top of the leaves.

An important element of the primary covering tissue of the leaves of the T. Bieberstein flower is the stomata, which provide the connection of the plant with the atmosphere. First of all, the stomatal apparatus performs a protective function. The closing cells of the stomata regulate the flow of gases, including protecting against excessive water loss. Phytoncides accumulate in the subcutaneous cavity, and prevent the penetration of pathogenic organisms into the plant. The regulatory function is associated with the implementation of a complex system of gas movement: the provision of photosynthesis with carbon dioxide, the removal of a strong oxidizer of oxygen [15]. The stomata of the leaves of the Bieberstein tulip flower slightly rise above the surface of the main epidermal cells. We managed to get a photo of such an epidermis by folding it in half through the stomata. The stomata are single, located randomly on the abaxial and adactal surfaces with different frequencies. The stomatal apparatus is of the anomocytic type, since the parotid cells are slightly different from the other cells of the epidermis. There are usually 4 parotid cells on the abaxial surface and up to 6-7 on the adaxial surface. They do not differ from the main epidermal cellsin shape and size, and a certain orientation is also not observed. The differences in stomata are related to the number in $1 \mathrm{~mm}^{2}$, the size of the closing cells, the distribution on the surface of the leaflet, and the shape (Fig. 5).

More stomata are located on the abaxial surface along the veins, there are no stomata on the edge of the leaflets. On the top of the outer side and the cup-shaped and corolla-shaped leaves, the maximum number of stomata is found: $42-45$ pieces per $1 \mathrm{~mm}^{2}$ (Table 1-2). By the base, they are observed to decrease to 32-33 pieces per $1 \mathrm{~mm}^{2}$.

On the adaxial side, they are rare and then the are only above the central veins. The stomatal coefficient is greater at the apex of the abaxial surface of the cup-shaped leaflet and is $24 \%$. At the same time, there are the largest main epidermal cells and the smallest stomata with a length of $0.05 \mathrm{~mm}$, a width of $0.04 \mathrm{~mm}$, and a length of the stomatal fissure of $0.02 \mathrm{~mm}$. It is $10-14 \%$. at the base of the abaxial surface of the cup-shaped leaflet and on the two surfaces of the corolla-shaped leaves. And the lowest stomatal coefficient is on the adaxial side of the cup-shaped leaflet $(0.2 \%)$. The closing cells of the stomata of the adaxial side of the cup-shaped petals were $0.14 \mathrm{~mm}$ and $0.18 \mathrm{~mm}$ more, which is 2.5 times larger than on the abaxial surface. The size of the stomata of the corolla-shaped leaflets does not differ much and is $0.05-0.07 \mathrm{~mm}$ long, 0.03-0.05 mm wide and 0.02-0.02 $\mathrm{mm}$ long of the stomatal fissure. The ratio of the length of the stomata to its width revealed differences in the types of stomata. The name also indicates a comparison of the degree of thickening of the cell walls. When the ratio of the length of the stomata to the width is equal to 0.9-1.2, the stomata are called spherical, differently thickened. Such stomata are found at the top of the abaxial surface of the calyx-shaped and corolla-shaped leaflets, as well as at the base and top of the adaxial surface of the calyx-shaped leaflets. The stomata have a navicular shape at the values of the length to width ratio of 1.8-2.3 and uneven thickening of the lateral cell walls. Such stomata are found at the base of the abaxial side of the cup-shaped and corolla-shaped leaflets. The predominance of stomata on the abaxial surface may be due to the close location of the chlorophyll-bearing tissue, which needs gas exchange. The location of many small stomata at the base of the leaflets creates conditions of high humidity, more constant temperature for the development of generative structures. The conditions of the closed chamber are supported by the hairs. 

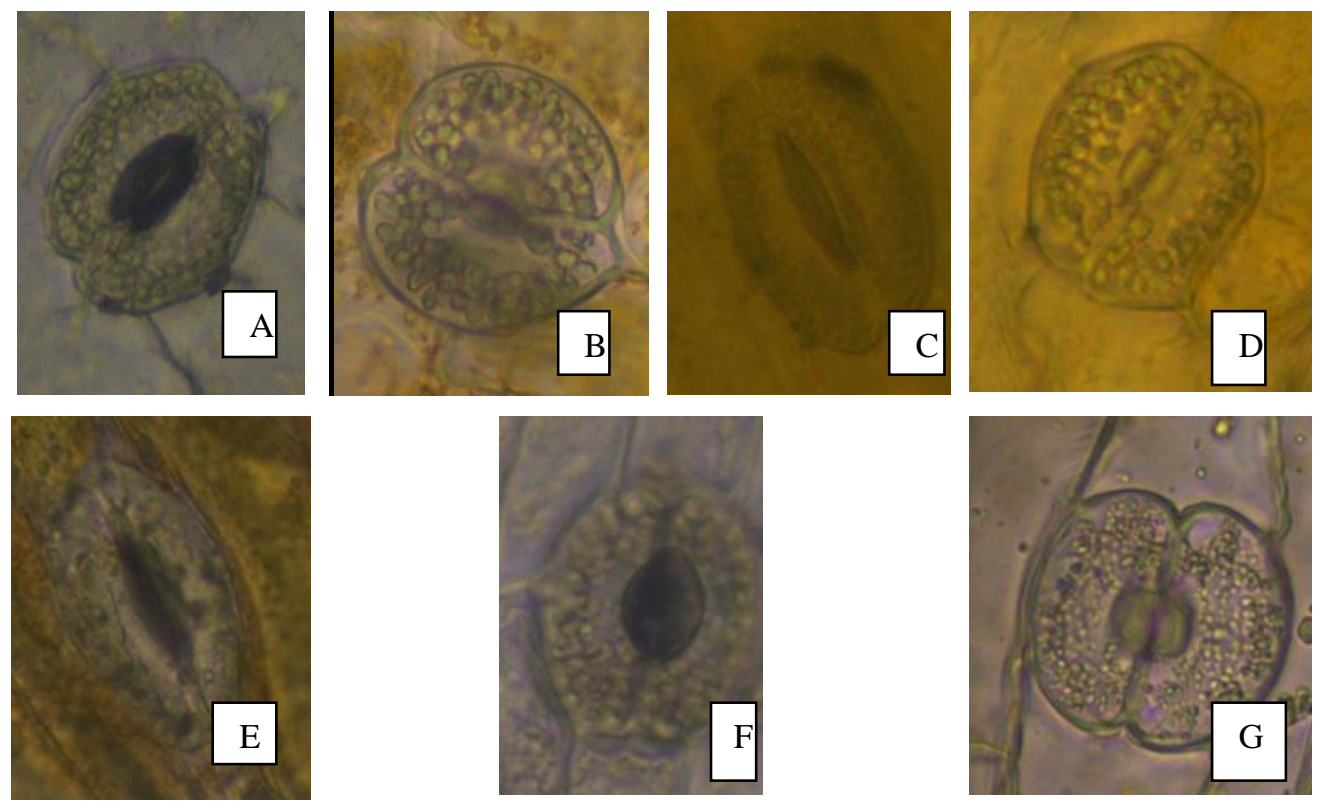

Fig. 5. Stomata (magnifying 1000): A - base checkvideo leaf, adaxial side, B - In the top of checkvideo leaf, adaxial side, C - checkvideo base of leaf, abaxial side, D - checkvideo the tip of leaf, abaxial side, E - the base of the Corolla of leaf, adaxial side, F - Corolla base of leaf, abaxial side, G the tip of the Corolla of leaf, abaxial side.

\section{Conclusion}

Thus, the revealed morpho-anatomical features of the structure of the Tulipa biebersteiniana flower in the south of the Central Russian Upland suggest that it retains the characteristics that support seed reproduction, despite the low real seed productivity during several years of observations.

\section{References}

1. A. G. Elenevsky, V. I. Radygina, N. N. Chaadaeva, Rasteniya Belgorodscoy oblasty,121 (2004)

2. E. V. Dumacheva, V. I. Cherniavskih, Kormoproizvodstvo,4 (2014)

3. E. V. Dumacheva, V. I. Cherniavskih, A. A. Gorbacheva, O. V. Vorobyova, Z. A. Borodaeva, E. N. Bespalova, L. R. Ermakova,. Int. J. of Green Pharmacy, 12, 2 (2018)

4. E. V.Dumacheva, V. I.Cherniavskih., V. K. Tokhtar, L. A. Tokhtar, T. A. Pogrebnyak., E.N. Horolskaya, A. A.Gorbacheva, O. V.Vorobyova, T. N.Glubsheva, E. I. Markova, S. V. Filatov, Int. J. of Green Pharmacy, 11, 3 (2017)

5. V. I. Cherniavskih, T. N.Glubscheva, Polevoij. biologa, 2, 2 (2020)

6. Glubsheva T. N., N. I. Sidelnikov, V. I. Cherniavskih, E. V.Dumacheva, S.E. Grigorenko,J. of Environmental Treatment Techniques,8(4)(2020)

7. G. E. Grosset, Bulletin MOIPT. LXXIII, 2(1968)

8. E. M. Lavrenko On vegetation of Pleistocene periglacial steppes of the USSR Bot. J.,V. 66, № 3, p. 313-327 (1981)

9. V. I. Chernyavskikh, E. V. Dumacheva, N. I. Sidelnikov, F. N. Lisetsky, L. Ch. Gagieva, J. of Ecology, 46, 2 (2019) 
10. M. V. Baranova, Mnogoletnie travyanistye rasteniya klassa Odnodol'nye v kollekcii otkrytogogruntaBotanicheskogosadaPetraVelikogoBINRAN(Rostock, St. Petersburg, 2013)

11. L. F. Yandovka, T. A. Loseva, Bulletin of Tambov University, Ser. Natural and technical Sciences, 18, 1 (2013)

12. M. G. Kotelnikova, Samarskiy naucny vestnik, 3, 16 (2016)

13. N. A. Kutlunina, M. V. Permyakova, M. A. Polezhaeva, Russian Journal of Genetics, 49, 4 (2013)

14. S. Ozodbek Abduraimov, F. Habibullo Shomurodov, A. Sultankul Daniyarov, S. Azizbek Abduraimov, J. of Botanical Research, 2, 04 (2020)

15. N. A. Aneli, Atlas epidermilista (Metznireba, Tbilisi, 1975)

16. L. I. Lotova, Morphology and anatomy of wild plants (Editorial URSS, Moscow, 2001) 